time as Emperor of Abyssinia. Among the chief awards announced by the President, V. Rossi, are those of the Bocconi Prize for cancer research to Prof. F. Pentimalli and the Cannizzaro Prize in chemistry to Prof. L. Ruzicka, Zurich. The following were elected as members during the preceding year A. Ghigi, D. de Blasi, P. G. Goidanich, L. Castiglioni, P. Ducati, A. Maiuri, P. de Francisci, F. Flora, as national members, and A. Carrelli, G. Polvani, F. Ercole, as corresponding members. The centenary of the death of the Italian poet, Giacomo Leopardi, was commemorated by an address given by $G$. Gentile.

\section{Royal Academy of Belgium: Prize Awards}

THe following prize awards have been announced by the Royal Academy of Belgium : the Théophile Cluge Prize to Dr. J. J. Bouckaert for his work on physiology; the Agathon De Potter Prize for astronomy to $\mathrm{S}$. Arend, for mathematics to $\mathrm{F}$. Bureau, for physics to J. Géhéniau, for chemistry to Prof. W. Mund, for mineralogy to E. Polinard, for biology to Z. M. Bacq and to L. Lison; the Schepkens Prize to J. Beirnaert for his work on genetics and the improvement of the oil palm; the Wetrems Prize to L. Coppens for his work on firedamp.

\section{Announcements}

Dr. L. J. Spencer, formerly keeper of minerals in the British Museum (Natural History), has been elected a corresponding member of the American Museum of Natural History, New York.

AT the general meeting at Indianapolis of the American Society of Plant Physiologists, Prof. Henry H. Dixon, of Trinity College, Dublin, was elected an honorary corresponding member of the Society.

Sir Walter Langdon-Brown and Prof. W. J. Dilling have been nominated by the Privy Council members of the council of the Pharmaceutical Society of Great Britain, in succession to Sir Humphry Rolleston and Prof. J. A. Gunn, who have retired. Sir Malcolm Delevingne will continue as the third member nominated by the Privy Council.

A commirmen has been appointed under the chairmanship of Mr. John Forster with two representatives of the Medical Research Council, Sir David Munro and Mr. Bradford Hill, two representatives of the London Passenger Transport Board, and two representatives of the Transport and General Workers Union to investigate the conditions of work and their effect on health of the London omnibus workers.

AT the annual general meeting of the Ray Society on March 24 the following officers were re-elected : President, Sir Sidney F. Harmer; Treasurer, Prof. F. E. Weiss ; Secretary, Dr. W. T. Calman. Prof. F. Balfour-Browne was elected a vice-president, and Dr. J. Ramsbottom and Mr. J. L. Chaworth-Musters new members of the council. It was announced that a translation by the late Sir Arthur Hort of the "Critica Botanica" of Linnæus will shortly be published and that among other works in preparation is one on the distribution and ecology of British spiders by Dr. W. S. Bristowe.

Dr. HeInRICH von Fischer, professor of meteorology at Vienna, has been made an honorary member of the German Meteorological Society and has been awarded the Silver Hillmann Medal by the Air Minister of the Reich.

The twenty-fourth Annual Conference of the National Association for the Prevention of Tuberculosis will be held at the British Medical Association House, Tavistock Square, W.C.1, on June 30-July 2.

THE Royal Sanitary Institute will hold a further course of instruction in disinfestation of houses and furniture from the bed-bug, beginning on May 16 . Further information can be obtained from the Secretary, 90 Buckingham Palace Road, S.W.1.

The All-India Population and Family Hygiene Conference will be held at Bombay on April 16-19 instead of in January as originally announced. Further information can be obtained from the Honorary Secretary, 8 Ormiston Road, Apollo Bunder, Bombay.

The third International Congress for Microbiology will be held at the Waldorf-Astoria Hotel, New York City, on September 2-9, 1939, under the auspices of the Intermational Association of Microbiologists and the presidency of Dr. T. M. Rivers, Rockefeller Institute for Medical Research, New York. Further information can be obtained from the General Secretary, Dr. M. H. Dawson, College of Physicians and Surgeons, 620 West 168th Street, New York, or from Dr. R. St. John-Brooks, Lister Institute, Chelsea Bridge Road, London, S.W.1.

THE International Federation for Documentation will hold its fourteenth International Conference on Documentation under the presidency of Sir William Bragg at Lady Margaret Hall, Oxford, on September 21-25. Members of the Conference will visit the Science Museum, London, on September 26. Advantage will be taken of the meeting being in England to hold joint sessions on the mornings of September 24-25 with the Association of Special Libraries and Information Bureaux. Further information can be obtained from the Secretary, Miss M. Gosset, The Science Library, South Kensington, London, S.W.7.

Gustav Fock, Leipzig, has issued an important catalogue listing close on 4,000 items, of which, in addition to journals and works of general zoology, the most extensive series deal with the physiology and biology of animals, psychology, zoogeography, and animals of economic importance. From Antiquariaat Junk, Den Haag (Holland), comes a list of 2,014 items concerning the one group Vermes. 